\title{
AN ANALYSIS OF TENSE AND ASPECT IN THE "TANGLED" MOVIE SCRIPT
}

\author{
Isti Endila Herani ${ }^{1}$, Cynantia Rachmijati ${ }^{2}$ \\ ${ }^{1}$ IKIP SILIWANGI \\ 2 IKIP SILIWANGI \\ ${ }^{1}$ istiherani@gmail.com ${ }^{2}$ cynan_tia@yahoo.com
}

\begin{abstract}
This study is an attempt to analyze the tense and aspects found inside the "Tangled" movie script. The data source is a sentence or speech the verb contains tense and aspects found on "Tangled" movie script. The study applied descriptive qualitative method.This study belongs to a descriptive research because it collects and analyzes the data, after that draws a conclusion based on the data. Then this research belongs to qualitative research because it involves analyzing and explaining the data. Additionally, this research is designed in descriptive qualitative research because the research examines the types of the language used of Tense and Aspects in "Tangled" Movie Scripts. In this research the data source is "Tangled" Movie Script.

In "Tangled" movie script, there was 61 sentences that researcher found in the uses of tense and aspect. From the result above the dominant types on tense and aspect in "Tangled" movie script was simple future and present perfect. In the "Tangled" movie script the researcher didn't find tense and aspect in past perfect progressive, future progressive, future perfect and future perfect progressive.
\end{abstract}

Keywords: tense, aspect, tangled movie script

\section{INTRODUCTION}

The Language is a communication system consisting of sounds, words, and grammar or communication systems that can express what a person feels and wants. According to Ondondo (2015 as cited in Wiguna \& Anggraeni, 2018), Understanding communication and how it works is important to human beings. In communication, there are many aspects that are used to convey the purpose of communication, one to clarify the purpose and intent to understand of the word to be conveyed is to learn grammar.

In learning English, one of the basic materials is studied grammar. Harmer (1991 as cited in Dewi, 2017) states "has declared that grammatical knowledge is very important for learners who wants to have communicative competence". Grammar is a structured rule in composing sentences, phrases, and words in the language. In the discourse analysis of grammar there is tense and aspect, tense and aspect is a semantic study used daily to communicate. According to McCarthly (1991 : 62 as cited Rivas, 2001), The tenses and aspects do not seem so strictly bound to time as to issues such as the sender's purpose, the focus on different elements of the message, and the projection of a shared framework within which thethe receiver will understand the message. Tense describes the occurrence an act now, past and future, while the aspect is related to the kinds of deeds, such as deeds continue to take place, are finished, and repeated.

In learning English a lot of media that can be used, one of them is using movie script. The researcher use movie scripts because it is interesting to be studied. In many movie scripts the 
use of tense and aspects that can be analyzed. From the above exposure, The researchers interested to examine the tangled movie script by Dan Fegelman for Pixar and Disney Movies Production because in the movie script there are tense and aspects that are used.

a. Tense and aspect system

Table 1. Tense and aspect system

\begin{tabular}{lll}
\hline Tenses & Aspects & Tense-aspect system \\
\hline Present & Simple & $\mathrm{S}+$ bare infinitive \\
& Progressive & $\mathrm{S}+$ am/ is/ are + present participle \\
& Perfect & $\mathrm{S}+$ have/ has + past participle \\
& Perfect progressive & $\mathrm{S}+$ have/ has + been + present participle \\
\hline Past & Simple & $\mathrm{S}+$ past simple \\
& Progressive & $\mathrm{S}+$ was/ were + present participle \\
& Perfect & $\mathrm{S}+$ had + past participle \\
& Perfect proressive & $\mathrm{S}+$ had + been + present participle \\
\hline Future & Simple & $\mathrm{S}+$ will + bare infinitive \\
& Progressive & $\mathrm{S}+$ will + be + present participle \\
& Perfect & $\mathrm{S}+$ will + have + past participle \\
& Perfect progressive & $\mathrm{S}+$ will + have + been + present participle \\
\hline
\end{tabular}

\section{b. "Tangled" Movie}

Tangled is a 2010 American 3D computer-animated with the genre musical adventure movie. Produced by Walt Disney Animation Studios and released by Walt Disney Pictures. This movie tells the story of a lost young princess with a long magical hair who yearns to leave her secluded tower. Against her mother's wishes, she accepts the aid of an intruder to take her out into the world which she has never seen. The researcher used the script of this movie because it is interesting to analysis this movie and this movie had tense and aspects in the dialogue of the script.

\section{METHOD}

In this research, the writer uses a descriptive qualitative research. Qualitative research is a research that gives the descriptive data in the form of written or oral words. According Denzin and Lincoln (2000:3 as cited in Ospina, 2004) claim that qualitative research involves an interpretive and naturalistic approach: "This means that qualitative researchers study things in their natural settings, attempting to make sense of, or to interpret, phenomena in terms of the meanings people bring to them". Tavakoli (2012:503) states in Kaswan \& Suprijadi (2016:15 as cited in Wiguna \& Anggraeni, 2018), Qualitative research is synthetic or holistic (i.e., views the separate parts as a coherent whole), heuristic (i.e., discovers or describes the patterns or relationships), with little or no control and manipulation of the research content.

This research belongs to a descriptive research because it just collects and analyzes the data, after that draws a conclusion based on the data. Then this research belongs to qualitative research because it involves analyzing and explaining the data.

Additionally, this research is designed in descriptive qualitative research because the research examines the types of the language used of Tense and Aspects in "Tangled" Movie Scripts. In 
this research the data source is "Tangled" Movie Script written by Dan Fegelman for Pixar and Disney Movies Production.

\section{RESULTS AND DISCUSSION}

\section{Results}

Table 2. The types of tense and aspet in the "Tangled" movie script

\begin{tabular}{|c|c|c|c|c|}
\hline & V1 & $\mathrm{Be}+\mathrm{V}$-ing & $3 \mathrm{H}+\mathrm{V} 3$ & $3 \mathrm{H}+\mathrm{Been}+\mathrm{V}$-ing \\
\hline & Simple & Proggressive & Perfect & $\begin{array}{c}\text { Perfect } \\
\text { Proggressive }\end{array}$ \\
\hline $\begin{array}{l}\text { Pres } \\
\text { ent }\end{array}$ & $\begin{array}{l}\text { S V1 (s/es) } \\
\text { 1.It starts with the } \\
\text { sun. } \\
\text { 2.Pascal motions } \\
\text { head. } \\
\text { 3.you lovely folks. } \\
\text { 4.Your dream } \\
\text { stinks. } \\
\text { 5.Mother says when } \\
\text { I was baby. } \\
\text { 6.It turns brown and } \\
\text { loses its. } \\
\text { Do/ does S V1? } \\
\text { Do you want go } \\
\text { outside? } \\
\text { Do you know what } \\
\text { these are? }\end{array}$ & $\begin{array}{l}\mathrm{S} \mathrm{am} / \text { is/ are } \mathrm{V} \text {-ing } \\
\text { 1.I am turning } \\
\text { eighteen. } \\
\text { 2.I am just teasing. } \\
\text { 3.I am leading up to } \\
\text { that. } \\
\text { 4.I am just saying. } \\
\text { 5.I think he is telling } \\
\text { the truth. } \\
\text { 6.The way it is } \\
\text { calling me. } \\
\text { 7.I am seeing those } \\
\text { lanters. } \\
\text { 8.Mother is feeling a } \\
\text { little run-down. }\end{array}$ & 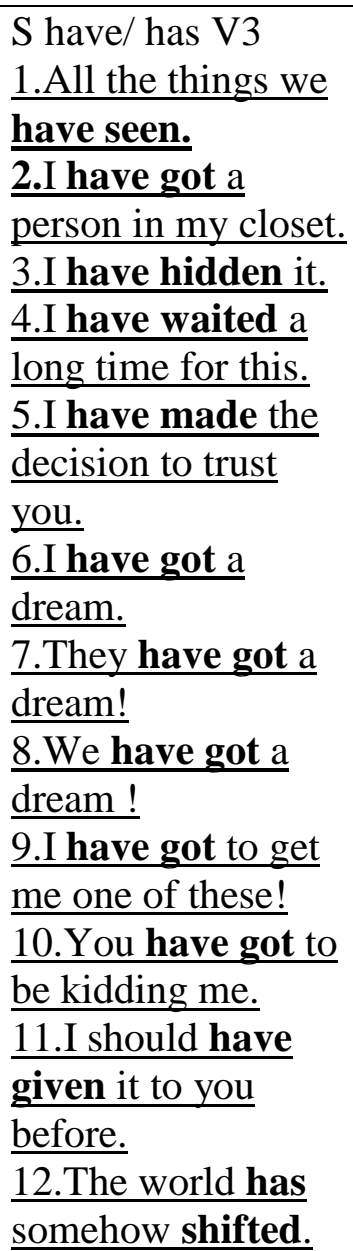 & $\begin{array}{l}\text { S have/ has been V- } \\
\text { ing } \\
\text { 1.I have been } \\
\text { dreaming about } \\
\text { them my entire life! } \\
\text { 2.I have been } \\
\text { looking out a } \\
\text { window for } \\
\text { eighteen years. } \\
\text { 3.I have been } \\
\text { searching for you } \\
\text { guys. } \\
\text { 4.I have been } \\
\text { hiding from you ! }\end{array}$ \\
\hline Pas & $\begin{array}{l}\mathrm{S} \text { V2 } \\
1 . \text { The kingdom } \\
\text { searched and } \\
\text { searched but they } \\
\text { could not find the } \\
\text { princess. } \\
\text { 2.I could get used to } \\
\text { a view like this. } \\
\text { 3.I wanted to ask. } \\
\text { S did } \text { not } \mathrm{V} 1 \\
1 . \text { I didn't see that } \\
\text { coming. }\end{array}$ & $\begin{array}{l}\text { S was/ were V-ing } \\
1 \text {. She was running } \\
\text { out of time. } \\
\text { 2.I was saying } \\
\text { tomorrow is a pretty } \\
\text { big day. } \\
\text { 3.I was hoping you } \\
\text { would take me to see } \\
\text { the floating lights. } \\
\text { 4.I was in a situation, } \\
\text { gallivanting through } \\
\text { the forest. }\end{array}$ & $\begin{array}{l}\mathrm{S} \text { had V3 } \\
1 . \text { He had enough } \\
\text { money to do } \\
\text { anything that he } \\
\frac{\text { wanted to do. }}{2 . \text { For the lost }} \\
\text { princess had now } \\
\text { returned. }\end{array}$ & - \\
\hline
\end{tabular}




\begin{tabular}{|c|c|c|c|c|}
\hline & $\begin{array}{l}\text { Did S V1? } \\
\text { 1. What did you do } \\
\text { to him? }\end{array}$ & $\begin{array}{l}\text { 5.I was being chased. } \\
\text { 6.I was talking to } \\
\text { her. } \\
\text { 7.I was going to offer } \\
\text { you something worth } \\
\text { one thousand crowns. } \\
\text { 8.I was starting to } \\
\text { think you ran off with } \\
\text { the crown and left } \\
\text { me. } \\
\text { 9.You were right } \\
\text { about everything. } \\
\text { 10.As I was saying, } \\
\text { tomorrow.. }\end{array}$ & & \\
\hline $\begin{array}{l}\text { Futu } \\
\text { re }\end{array}$ & 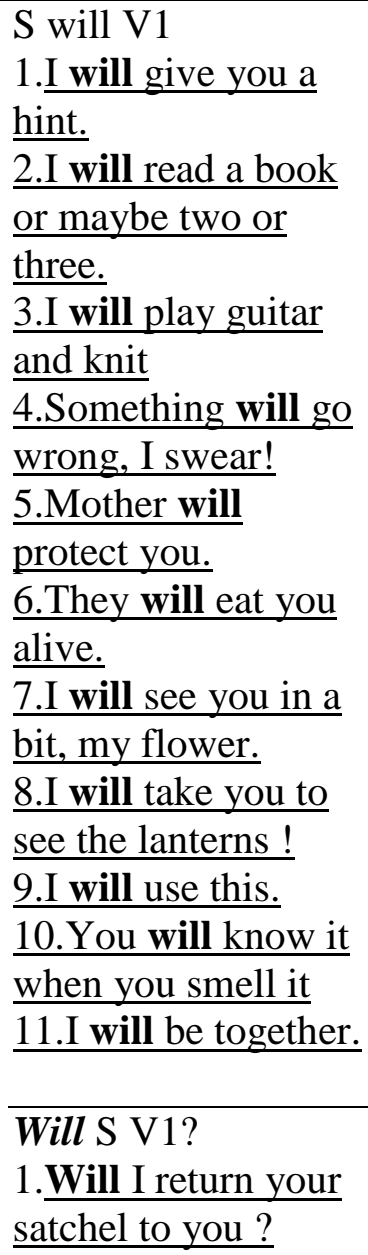 & - & - & - \\
\hline
\end{tabular}

The researchers used two samples of each types to discuss of tense and aspect in "Tangled" movie script.

1). Present simple :

a. Mother says when I was baby

The tense in the sentence states the present, and the aspect in the sentence states

is going.

b. It starts with the sun.

The tense in the sentence states the present, and the aspect states is going

2). Present progressive : 
a. I am turning eighteen.

The tense in the sentence states the present, and the aspect in the aspect states the sentence is going.

b. Mother is feeling a little run-down.

The tense in the sentence states the present, and the aspect the aspect states the sentenceis going.

3). Present perfect :

a. I have waited a long time for this.

The tense states the sentence is present, and the aspect states the sentence is has been done.

b. I have made the decision to trust you.

The tense in the sentence states the present, and the aspect states the sentence is has been done.

4). Present perfect progressive :

a. I have been dreaming about them my entire life !

The tense in the sentence states the present, and the aspect states the sentence that continuous.

b. I have been looking out a window for eighteen years.

The tense in the sentence states the present, and the aspect states the sentence that continuous.

5). Past simple :

a. The kingdom searched and searched but they could not find the princess.

The tense in the sentence states the past, and the aspect states the sentence that continuous.

b. I could get used to a view like this.

The tense in the sentence states the past, and the aspect states the sentence that continuous.

6). Past progressive :

a. I was saying tomorrow is a pretty big day.

The tense in the sentence states the past, and the aspect states the sentence that continuous.

b. I was hoping you would take me to see the floating lights.

The tense in the sentence states the past, and the aspect states the sentence that continuous.

7). Past perfect :

a. For the lost princess had now returned.

The tense in the sentence states the past, and the aspect states the sentence that completed.

b. He had enough money to do anything that he wanted to do.

The tense in the sentence states the past, and the aspect states the sentence that completed.

8). Future simple :

a. I will take you to see the lanterns!

The tense in the sentence states the future, and the aspect states the sentence is going.

b. They will eat you alive.

The tense in the sentence states the future, and the aspect states the sentence is going. 


\section{Discussion}

Based on the research finding table, it can be concluded the types tense and aspect in the "Tangled" movie script were present simple (6 sentences), present progressive ( 8 sentences), present perfect (12 sentences), present perfect progressive (4 sentences), past simple (3 sentences), past progressive (10 sentences), past perfect ( 2 sentences) and future simple (12 sentences) . Based on the two samples of each types to discuss of tense and aspect in "Tangled" movie script the researcher used :

1). Tense

a. Tense which states in the past is searched, used, was saying, was hoping, had now, returned, had enough, and wanted.

b. Tense which states in the present is says, starts, turning, feeling, have been dreaming, have been hoping, have made and have waited.

2). Aspect

c. Tense which states in the future is will take and will use.

a. Aspect which states in the the sentence has been done is have waited and have made.

b. Aspect which states in the the sentence was going is says, starts, turning, feeling, will take and will use.

c. Aspect which states in the the sentence that continuous is was saying, was hoping, searched, used, have been dreaming and have been hoping.

d. Aspect which states in the the sentence that completed is had now, returned, had enough, and wanted.

\section{CONCLUSION}

The types of tense and aspect that used in "Tangled" movie script were present simple, present progressive, present perfect, present perfect progressive, past simple, past progressive, past perfect and future simple. In "Tangled" movie script, there was 61 sentences the researcher found in the uses of tense and aspect. In the "Tangled" movie script the researcher didn't find tense and aspect in past perfect progressive, future progressive, future perfect and future perfect progressive. From the result above the dominant types on tense and aspect in "Tangled" movie script was simple future and present perfect.

Based on the two samples of each types to discuss of tense and aspect in "Tangled" movie script the researcher used, Tense in "Tangled" movie script are searched, used, was saying, was hoping, had now, returned, had enough, wanted says, starts, turning, feeling, have been dreaming, have been hoping, have made have waited, will take and will use. Aspect in "Tangled" movie script are have waited, have made, says, starts, turning, feeling, will take, will use, was saying, was hoping, searched, used, have been dreaming, have been hoping, had now, returned, had enough, and wanted.

\section{ACKNOWLEDGMENTS}

First, I would like to thank to Allah because of His blessing and guidance I could finish my journal. This journal have not been completed without support, guidance from individual and institution. Therefore, the researcher would likes to express special thanks to:

1. Cynantia Rachmijati, M.M.Pd as the advisor for their guidance and help to finish this journal. 
2. Other researcher for references in tense and aspect.

3. My beloved friends and family to giving support, motivation and gives me strength to finish my study.

4. The Lectures and staffs in English Departement in IKIP SILIWANGI.

\section{REFERENCES}

Dewi, E. M. (2017). Improving Students' Grammar Using Dictogloss. Syiah Kuala University, Banda Aceh, 8(3), 352-366. Retrieved from http://www.jurnal.unsyiah.ac.id/EEJ/article/viewFile/8928/7075

Ospina, S. (2004). Qualitative Research. SAGE Publications. Retrieved from https://ualr.edu/interdisciplinary/files/2010/03/Qualitative_Research.pdf

Rivas, M. (2001). Aspect variation in narrative: a discourse approach. Universidad de Sevilla, 2, 225-237. Retrieved from http://institucional.us.es/revistas/elia/2/17rivas.pdf

Tangled movie script. (2010). Retrieved from https://www.springfieldspringfield.co.uk/movie_script.php?movie=tangled.

Wiguna, A., \& Anggraeni, H. (2018). Deixis in Maleficent Movie Script. IKIP SILIWANGI, 1(2), 133-138. Retrieved from

https://journal.ikipsiliwangi.ac.id/index.php/project/article/view/466 